\title{
KESULITAN GURU DALAM PEMBELAJARAN PENDIDIKAN AGAMA ISLAM DAN BUDI PEKERTI BERDASARKAN KURIKULUM 2013 DI SMP NEGERI 6 KOTA MAKASSAR
}

\author{
Umar \\ Fakultas Tarbiyah Institut Agama Islam Muhammadiyah Bima \\ Kampus: Jalan Anggrek No. 16, Ranggo Na'e \\ Email: laodeumarPGMI@gmail.com
}

\begin{abstract}
Abstrak:
Penelitian ini bertujuan untuk mendeskripsikan kesulitan guru dalam pembelajaran Pendidikan Agama Islam dan Budi Pekerti berdasarkan Kurikulum 2013 di SMP Negeri 6 Kota Makassar. Jenis penelitian yang digunakan tergolong kualitatif dengan asas pendekatan fenomenologis. Sumber data terdiri atas guru mata pelajaran PAI dan Budi Pekerti, kepala sekolah, wakasek kurikulum, pengawas dan peserta didik. Instrumen pengumpulan menggunakan lembar observasi, pedoman wawancara, studi dokumentasi dan penelusuran referensi. Teknik analisis data penelitian menggunakan model analisis Miles dan Huberman melalui tiga tahapan, yaitu: reduksi data, penyajian data, penarikan kesimpulan, dan pengujian keabsahan data. Hasil penelitian menunjukan bahwa dalam melaksanakan pembelajaran berdasarkan Kurikulum 2013, guru mengalami beberapa kesulitan seperti; sulit memilih model pembelajaran yang variatif sesuai dengan pola belajar saintific approach, masih sukar melakukan penyusunan instrumen maupun rubrik-rubrik penilaian, dan masih sulit melaksanakan penilaian proses. Tetapi, secara umum para guru mengalami kesulitan pada apek penilaian authentic assessment pembelajaran berdasarkan Kurikulum 2013.
\end{abstract}

\begin{abstract}
:
This research aimed at describing the teachers' difficulties in teaching Islamic education and character based on curriculum 2013 at SMPN 6 Makassar. This Research used qualitative by using phenomenologis8t approach. The data were obtained from the teachers of Islamic education, the head master, and the vice head master of curriculum concerns, advisor and students. Data were collected from observation, interview, documentation tools, triangulation, and literature review. Then the data were analyzed by using Miles' and Huberman's model analysis through four steps namely; data reduction, data presentation, drawing conclusion and data validation. The research finding shows that in conducting learning process based on curriculum 2013, teachers encountered some difficulties in teaching such as; they find difficulty to choose the suitable instructional model related to scientific approach, they encountered difficulties in making instruments and evaluation formats, and they also faced difficulties in the process of evaluation. But, generally, they encountered more difficulties in using authentic assessment of the curriculum 2013.
\end{abstract}

Kata kunci:

Kesulitan Guru, Pembelajaran PAI, Kurikulum 2013

PEMERINTAH menjelaskan, lahirnya Kurikulum 2013 di arahkan untuk menjawab tantangan dan pergeseran paradigma pembangunan dari abad ke-20 menuju abad ke- 
21. Kurikulum 2013 bertujuan untuk mempersiapkan manusia Indonesia agar memiliki kemampuan hidup sebagai warga negara yang beriman, produktif, kreatif, inovatif serta mampu berkontribusi pada kehidupan bermasyarakat, berbangsa, bernegara, dan peradaban dunia. ${ }^{1}$ Sehingga pengembangan kurikulum sangat diperlukan untuk mengikuti perkembangan zaman dan menjawab tantangan masa depan yang semakin lama semakin rumit dan kompleks dan nantinya akan dihadapi bangsa Indonesia. Tantangan masa depan tersebut antara lain berkaitan dengan arus globalisasi dan pasar bebas, masalah lingkungan hidup, pesatnya kemajuan teknologi informasi, kebangkitan industri kreatif dan budaya, pergeseran kekuatan ekonomi dunia, maupun pengaruh mutu investasi dan transformasi pada sektor pendidikan. Jika tantangan tersebut tidak segera direspons, maka akan kehilangan momentum untuk mempersiapkan generasi emas 100 tahun Indonesia merdeka pada tahun $2045 .{ }^{2}$

Ketetapan pemerintah tentang pembaharuan pendidikan dengan lahirnya Kurikulum 2013, memiliki muatan dan visi yang sangat baik untuk kemajuan bangsa dan negara. Namun, seperti dapat disimak dalam pemberitaan, baik melalui media massa ataupun media sosial, perubahan itu telah menimbulkan polemik di dalam masyarakat, ada yang pro dan ada yang kontra. Pemicunya antara lain: kesatu, penghilangan mata pelajaran IPA dan IPS dari kurikulum SD dan SMP menjadi pembelajaran integrative science dan integrative sosial. Kedua, penghapusan mata pelajaran teknologi informatika (TI). Ketiga, upaya penyiapan guru sebagai ujung tombak pelaksanaan kurikulum belum disiapkan dengan baik oleh pemerintah. ${ }^{3}$ Kontroversi akan lahirnya Kurikulum 2013 dengan segala bentuk isinya, memberikan gambaran bahwa perubahan kurikulum secara tidak langsung menimbulkan dampak signifikan terhadap kegiatan pembelajaran sebagai akibat dari adanya transisi dari Kurikulum Tingkat Satuan Pendidikan (KTSP 2006) menjadi Kurikulum 2013. Dampak perubahan tersebut berimplikasi cukup besar terhadap kinerja guru dalam menyelenggarakan pendidikan di sekolah termasuk dalam proses pembelajaran di berbagai bidang studi seperti pembelajaran Pendidikan Agama Islam dan Budi Pekerti.

Berdasarkan observasi awal penulis terhadap guru pada SMP Negeri 6 Kota Makassar menunjukkan bahwa masih banyak kendala-kendala yang dihadapi oleh guru dalam mengimplementasi Kurikulum 2013. Kendala-kendala itu muncul misalnya bahan ajar yang tidak terpenuhi, implementasinya di dalam pembelajaran sulit dilakukan, dan sistim evaluasi pembelajaran yang rumit. Keterangan beberapa guru tersebut diperkuat oleh kepala sekolah yang menjelaskan bahwa pelaksanaan Kurikulum 2013 di sekolah belum sepenuhnya dapat diimplementasi karena faktor-faktor teknis dan non-teknis yang disebut oleh guru.

Wakil kepala sekolah bidang kurikulum secara spesifik menuturkan bahwa pelaksanaan Kurikulum 2013 masih menghadapi banyak masalah, seperti; kesiapan tim pengajar yang belum memadai dan ketersediaan bahan ajar bagi guru yang belum juga terpenuhi. Berdasarkan pengamatan awal ini, penulis tertarik melakukan penelitian untuk merespons masalah yang berkembang terkait lahirnya Kurikulum 
2013. Besar harapan penulis, penelitian ini mampu memberikan gambaran secara objektif khususnya kondisi aktual guru ketika melaksanakan pembelajaran di kelas.

Berangkat dari ketiga rumusan masalah tersebut, tujuan penelitian dapat dirumuskan sebagai berikut:

1. Untuk mendeskripsikan pemahaman guru mata pelajaran Pendidikan Agama Islam dan Budi Pekerti tentang Kurikulum 2013 di SMP Negeri 6 Kota Makassar.

2. Untuk mendeskripsikan kesulitan guru dalam melaksanakan pembelajaran mata pelajaran Pendidikan Agama Islam dan Budi Pekerti berdasarkan Kurikulum 2013 di SMP Negeri 6 Kota Makassar.

3. Untuk mengungkap faktor-faktor pendukung dan penghambat guru mata pelajaran Pendidikan Agama Islam dan Budi Pekerti dalam pelaksanaan Kurikulum 2013 di SMP Negeri 6 Kota Makassar.

4. Untuk mendeskripsikan upaya guru mata pelajaran Pendidikan Agama Islam dan Budi Pekerti mengatasi kelemahan implementasi Kurikulum 2013 di SMP Negeri 6 Kota Makassar

\section{TINJAUAN TEORETIS}

\section{Guru Dalam Proses Pembelajaran}

Dalam bahasa Inggris, ditemukan beberapa kata yang berkaitan dengan guru, yaitu; teacher, tutor, instructor, dan educator. Merujuk penjelasan Kamus Webster's, teacher diartikan seseorang yang mengajar; tutor diartikan seseorang guru yang memberikan pengajaran terhadap siswa; instructor diartikan seseorang yang mengajar; dan educator, diartikan dengan seseorang yang mempunyai tanggung jawab pekerjaan mendidik yang lain. ${ }^{4}$ Sedang dalam Kamus Besar Bahasa Indonesia dipersepsikan sebagai orang yang pekerjaannya (mata pencahariannya/ profesinya) mengajar. ${ }^{5}$

Menurut istilah, Daradjat mendefinisikan guru sebagai pendidik profesional yang senantiasa merelakan dirinya menerima dan memikul sebagian tanggung jawab yang terpikul di pundak orang tua. ${ }^{6}$ Ahmad Tafsir mengartikan guru sebagai pendidik yang memberikan pelajaran kepada murid; biasanya pendidik yang memegang mata pelajaran di sekolah dan bertanggung jawab terhadap berlangsungnya proses perkembangan dan pertumbuhan potensi anak didik, baik potensi psikomotorik, kognitif, maupun afektifnya. ${ }^{7}$ Sejalan dengan itu, Getteng menulis, secara redaksional guru diartikan sebagai orang yang mempunyai kedudukan untuk membimbing, mengarahkan, dan memelihara peserta didiknya baik dari segi fisik maupun psikis sehingga memudahkan dalam pembangunan peradaban masa depan melalui eksperimen atas problematika yang muncul dalam kehidupan masyarakat. ${ }^{8}$

Perkembangan profesi guru tidak pernah lepas dari tugas dan tanggung jawab dalam melaksanakan proses pendidikan bagi peserta didik di lingkungan pendidikan. Meski harus diakui, beban tugas dan tanggung jawab dialamatkan pada profesi guru terbilang besar bila dibandingkan dengan penghargaan jasa yang dipertanggungkan kepadanya. Misalnya; guru diharapkan dapat mengampuh pembelajaran agar peserta didiknya berubah dari tidak tahu menjadi tahu, dari perilaku kurang 
baik menjadi lebih baik, dan dari tidak bisa menjadi bias melakukan. Di satu sisi, ketika anak didik tidak berhasil mencapai kompetensinya, maka guru adalah pihak yang paling pertama disalahkan.

Dilematis, namun guru dalam perannya dituntut untuk tahu dan paham akan tugas dan tanggung jawab profesionalnya, terutama sebagai pengemban pembelajaran di lingkungan sekolah. Merujuk kepada Undang-Undang RI Nomor 20, tahun 2003 tentang Sistem Pendidikan Nasional (UU Sisdiknas) BAB XI, pasal 39 butir (2) secara umum pendidik disebut sebagai tenaga profesional bertugas merencanakan, melaksanakan proses pembelajaran, menilai hasil belajar, melakukan pembimbingan dan pelatihan, serta melakukan penelitian dan pengabdian kepada masyarakat, terutama bagi pendidik pada perguruan tinggi. ${ }^{9}$ Jabaran lanjutan, perihal tugas guru juga dijelaskan dalam Undang-Undang RI Nomor 14, tahun 2005 tentang Guru dan Dosen BAB I, pasal 1 butir (1), menyebutkan tugas guru sebagai berikut:

Guru adalah pendidikan profesional dengan tugas utama mendidik, mengajar, membimbing, mengarahkan, melatih, menilai, dan mengevaluasi peserta didik pada pendidikan anak usia dini jalur pendidikan formal, pendidikan dasar, dan pendidikan menengah. ${ }^{10}$

Selain persoalan tugas, guru sebagai pendidik profesional juga diikat dengan satu amanah untuk menerima dan memikul sebagian tanggung jawab pendidikan yang terpikul di pundak para orang tua. Tanggung jawab yang diterima oleh guru dalam mendidik bukan berarti menghilangkan esensi tanggung jawab orang tua sebagai pendidik pertama dan utama bagi anak atau peserta didik. Akan tetapi tanggung jawab guru yang dimaksud, lebih menekankan pada visi mencerdaskan peserta didik dalam ranah intelektual, emosional dan spiritual yang sesuai dengan tujuan pendidikan Islam ataupun tujuan pendidikan nasional.

Hamalik dalam Getteng mengatakan bahwa secara umum tanggung jawab yang harus diemban guru meliputi:

a. Tanggung jawab moral yang menekankan pada sikap seorang guru yang menjunjung tinggi nilai-nilai susila, khususnya di lingkungan pendidikan seperti tutur kata, perilaku ataupun tingkah lakunya dalam proses pembelajaran.

b. Tanggung jawab dalam bidang pendidikan. Substansi tanggung jawab bidang pendidikan menekankan kinerja guru di lingkungan pendidikan seperti merencanakan, melaksankan, dan mengevaluasi pembelajaran untuk peserta didik.

c. Tanggung jawab guru dalam bidang kemasyarakatan. Penekanan tanggung jawab guru dalam bidang kemasyarakatan berkaitan dengan pembangunan hubungan sosial antara guru dan masyarakat seperti penyuluhan masyarakat, ingintasan buta aksara, dan lain sebagainya.

d. Tanggung jawab dalam bidang keilmuan yaitu tanggung jawab dari sisi kesadaran guru untuk mengembangkan ilmu pengetahuan seperti; meningkatkan wawasan keilmuan, dan mengamalkan ilmu pengetahuan untuk mencerdaskan orang lain. ${ }^{11}$

Uraian tentang tugas dan tanggung jawab guru, paling tidak menerangkan beberapa hal yang dapat dipahami. Pertama, menjelaskan bahwa guru merupakan 
profesi dengan tugas yang sangat kompleks. Semua tugas yang dibebankan kepada guru secara umum berkaitan dengan upaya mentransformasi nilai-nilai kepada orang lain dalam tiga ranah utama: afeksi, kognisi, dan psikomotor. Dalam kaitan itu, guru merupakan figur yang berkontribusi ril dalam optimalisasi pertumbuhan dan perkembangan peserta didik khususnya dalam lingkungan pendidikan. Kedua, secara filosofis tanggung jawab guru diititikberatkan pada serangkaian aktivitas kependidikan yang berlaku dalam lingkungan sekolah, khususnya dalam pengembangan potensi peserta didik. Ketiga, mengungkapkan dimensi tanggung jawab guru meliputi berbagai aspek seperti; moral, pendidikan, keilmuan, dan kemasyarakatan yang kesemuanya menunjukan bahwa guru merupakan sebuah profesi yang mendedikasikan dirinya untuk kemaslahatan orang lain. Keempat, secara implisit bahwa prototype tugas dan tanggung jawab guru profesional memikul beban moral dalam rangka memajukan nilai-nilai pendidikan dan sosial kemasyarakatan.

Penjelasan di atas menunjukkan bahwa keberadan guru di dalam suatu pembelajaran hakikatnya adalah pengejewantahan dari pelaksanaan tugas dan tanggung jawab profesional pendidik bagi pengembangan karakter peserta didik di tingkat satuan pendidikan.

\section{Konsep Pembelajaran Kurikulum 2013}

Kurikulum 2013 merupakan kurikulum baru yang mulai diterapkan pada tahun pelajaran 2013/2014. Kurikulum ini adalah hasil dari serentetan penyempurnaan terhadap kurikulum yang ada sebelumnya, yakni Kurikulum Berbasis Kompetensi (KBK) tahun 2004 dan Kurikulum Tingkat Satuan Pendidikan (KTSP) pada tahun 2006. Secara umum, Kurikulum 2013 dapat diartikan sebagai kurikulum yang dikembangkan untuk meningkatkan dan menyeimbangkan kemampuan soft skill dan hard skill yang berupa kompetensi sikap, keterampilan dan pengetahuan. ${ }^{12}$

Mulyasa mengungkapkan bahwa Kurikulum 2013 termasuk kurikulum berbasis kompetensi serta dapat dimaknai sebagai suatu konsep kurikulum yang menekankan pada pengembangan kemampuan melakukan tugas-tugas dengan standar performasi tertentu, sehingga hasilnya dapat dirasakan oleh peserta didik, berupa penguasaan kompetensi. Lebih lanjut, dia menambahkan bahwa kurikulum ini diarahkan untuk mengembangkan pengetahuan, pemahaman, kemampuan, nilai, sikap, dan minat peserta didik agar dapat melakukan sesuatu dalam bentuk kemahiran, ketepatan, serta keberhasilan dengan penuh tanggung jawab. ${ }^{13}$

Konsep pembelajaran Kurikulum 2013 menggunakan pendekatan scientific. Pendekatan scientific merupakan pendekatan pembelajaran yang menuntut peserta didik untuk beraktivitas sebagaimana seorang ahli sains. Dalam praktiknya, peserta didik diharuskan melakukan serangkaian aktivitas selayaknya langkah-langkah dalam metode ilmiah seperti merumuskan masalah, mengumpulkan data, mengolah dan menganalisis, serta membuat kesimpulan. ${ }^{14}$ Bila mengacu pada penjabaran Kementerian Pendidikan dan Kebudayaan, langkah pembelajaran pendekatan scientific meliputi mengamati (observing), menanya (questioning), mencoba (experimenting), menalar (associating), dan mengomunikasikan (communicating). ${ }^{15}$ Selain persoalan pendekatan 
pembelajaran, Kurikulum 2013 sangat menekankan proses penilaian pembelajaran yang berbasis authentic assessment. Penilaian autentik merupakan sebutan untuk menggambarkan tugas-tugas riel peserta didik yang dilaksanakan dalam menghasilkan pengetahuan memproduksi informasi. Menurut Johnson dalam Abidin, penilaian autentik pada dasarnya adalah penilaian performa yakni penilaian yang dilakukan untuk mengetahui pengetahuan dan keterampilan peserta didik selama proses pembelajaran dalam mencapai produk dan keterampilan tertentu. ${ }^{16}$

Merujuk penjelasan Permendikbud Nomor 66 tahun 2013 tentang Standar Penilaian Pendidikan BAB II, secara umum dapat diuraikan bahwa penilaian autentik meliputi penilaian kompetensi sikap, penilaian kompetensi pengetahuan, dan penilaian kompetensi keterampilan. Dalam penjabarannya, penilaian kompetensi sikap mencakup penilaian diri, penilaian antar teman dan jurnal. penilaian kompetensi pengetahuan meliputi tes lisan, tes tulis dan penugasan, sedangkan penilaian keterampilan tardiri dari tes praktik, projek, dan penilaian portofolio. ${ }^{17}$

Penjelasan di atas menunjukkan bahwa autentic assessment merupakan suatu bentuk penilaian yang diarahkan kepada penilaian proses dan tugas belajar secara holistik dalam kegiatan pembelajaran. Pelaksanaan penilaian autentik pada Kurikulum 2013 diharapkan mampu mengukur secara maksimal terkait peningkatan kompetensi peserta didik dalam berbagai aspeknya. Kaitannya dengan model pembelajaran Kurikulum 2013. Dalam penjabaran Permendikbud Nomor 65 tahun 2013 tentang Standar Proses Pendidikan Dasar dan Menengah BAB II, disebutkan beberapa model pembelajaran yang dapat dilaksanakan oleh guru dalam mendesain pembelajaran yang relevan dengan konten Kurikulum 2013 antara lain model pembelajaran inkuri (inquiry learning), model pembelajaran diskoveri (discovery learning), model pembelajaran berbasis proyek (problem based learning), dan model pembelajaran berbasis masalah (project based learning). ${ }^{18}$

Mencermati uraian di atas, dapat dipahami bahwa konsep pembelajaran dalam Kurikulum 2013 lebih banyak memberikan ruang bagi peserta didik untuk mengeksplorasi dan mengkonstruksi pengetahuan awalnya sedang guru berperan sebagai fasilitator pembelajaran. Penekanan pembelajaran tersebut sejalan dengan gagasan pendidikan humanis yang dikemukakan oleh Freire yaitu sistim pendidikan "problem posing education" atau "pendidikan hadap masalah" yang memungkinkan guru dan peserta didik bersama-sama menjadi subjek dan objek pengetahuan. Di samping itu, guru menjadi rekan peserta didik yang melibatkan diri untuk merangsang daya berpikir kritis peserta didik. ${ }^{19}$

\section{METODE PENELITIAN}

Penelitian ini adalah penelitian kualitatif yang dilaksanakan di SMP Negeri 6 Kota Makassar. Proses penelitian menggunakan pendekatan fenomenologi, yakni suatu pendekatan penelitian yang berusaha untuk memahami suatu fakta, gejalagejala, maupun peristiwa yang bentuk keadaannya dapat diamati dan dinilai lewat kaca mata ilmiah. ${ }^{20}$ Data penelitian bersumber dari guru Pendidikan Agama Islam 
dan Budi Pekerti, kepala sekolah, wakil kepala sekolah, pengawas, dan peserta didik serta dokumen pendukung lainya. Teknik pengumpulan data dilakukan melalui tahap observasi, wawancara dokumentasi, dan triangulasi. Sisi lainnya, pelaksanaan pengumpulan data didukung dengan penggunaan intrumen penelitian mencakup pedoman observasi dan pedoman wawancara.

Selanjutnya data yang diperoleh dari hasil wawancara, catatan lapangan, dan bahan-bahan lainnya, dianalisis dan diintepretasi dengan menggunakan metode analisis dan interpretasi data yang relevan dengan kebutuhan penelitian. Kaitannya dengan penelitian ini, metode analisis dan interpretasi data yang digunakan oleh peneliti mengikuti model analisis Miles dan Huberman dengan langkah-langkah: reduksi data (data reduction), penyajian data (data display), dan penarikan kesimpulan (conclusion). Penggunaan metode analisis dan interpretasi bertujuan memberikan penjelasan secara deskriptif agar membantu pembaca mengetahui apa yang terjadi di lingkungan pengamatan, seperti apa pandangan partisipan yang berada di latar penelitian. ${ }^{21}$ Deskripsi yang cukup dan pernyataan langsung dimaksudkan untuk membantu pembaca memahami secara penuh dari pemikiran orang yang terwakili secara naratif, terkait kesulitan guru dalam melaksanakan proses pembelajaran Pendidikan Agama Islam dan Budi Pekerti berdasarkan Kurikulum 2013 di SMP Negeri 6 Kota Makassar.

\section{HASIL DAN PEMBAHASAN}

\section{Pemahaman Guru Mata Pelajaran Pendidikan Agama Islam dan Budi Pekerti Tentang Kurikulum 2013 di SMP Negeri 6 Kota Makassar}

Guru merupakan aktor utama dalam mendesain kegiatan pembelajaran pada setiap satuan pendidikan. Dalam peran itu, guru diharuskan memahami segala bentuk tindakan yang akan mereka lakukan dalam melaksanakan pembelajaran bagi peserta didiknya berdasarkan tingkat perubahan regulasi kependidikan, seperti perubahan kurikulum. Terkait pemahaman guru mata pelajaran Pendidikan Agama Islam dan Budi Pekerti tentang Kurikulum 2013 di SMP Negeri 6 Kota Makassar, terdapat dua indikator yang menjadi parameter temuan penulis di lingkungan penelitian meliputi: sikap guru PAI terhadap Kurikulum 13 dan pengetahuan guru PAI tentang kurikulum itu.

\section{Sikap Guru Terhadap Kurikulum 2013}

Kebijakan pengembangan kurikulum KTSP 2006 menjadi Kurikulum 2013 berdampak langsung terhadap mental guru selaku agen pelaksana di tingkat satuan pendidikan. Efek perubahan kurikulum tersebut turut memengaruhi sikap para guru dalam menjelaskan tugas keprofesiannya. Kaitannya dengan sikap guru mata pelajaran Pendidikan Agama Islam dan Budi Pekerti terhadap Kurikulum 2013 di SMP Negeri 6 Kota Makassar, hasilnya menunjukan bahwa guru PAI dan Budi Pekerti pada umumnya setuju dengan pelaksanaan Kurikulum 2013. Alasan setuju tersebut adalah sebagai berikut: 
a. Pemberlakuan Kurikulum 2013 sudah menjadi ketentuan pemerintah dan harus dilaksanakan.

b. Kurikukum 2013 yang mengarah pada pembentukan karakter anak didik, serta lebih banyak memberikan kesempatan bagi peserta didik untuk mengungkapkan pengetahuan.

c. Kurikulum 2013 sangat dibutuhkan karena muatan ajaran kurikulumnya membantu guru agama, bahkan dapat dikatakan Kurikulum 2013 adalah kurikulum berwarna ijo yang kental dengan nuansa keagamaan serta menekankan pembentukan sikap.

d. Guru Pendidikan Agama Islam dan Budi Pekerti umumnya menerima pemberlakuan Kurikulum 2013, dan berusaha melengkapi segala kekurangan pada saat melaksanakan pembelajaran berdasarkan Kurikulum 2013.

Gambaran pernyataan guru, bila ditelaah bahwa sikap setujunya guru terkait pemberlakuan Kurikulum 2013 di sekolah tersebut merupakan satu konsekuensi pelaksanaan kebijakan pemerintah pada sektor pembangunan pendidikan, sehingga menuntut para guru suka atau tidak harus melaksanakan pembelajaran berdasarkan Kurikulum 2013. Di satu sisi, adanya sikap menerimanya guru terhadap pemberlakuan Kurikulum 2013, karena didorong oleh konten kurikulum yang menekankan pembentukan sikap peserta didik dinilai sangat relevan dengan konsep pembelajaran pendidikan Agama Islam yang senantiasa mengedepankan tentang nilai akhlak dan lain sebagainya. Bahkan, meskipun terungkap refleksi psikis guru agama yang menyatakan pelaksanaan Kurikulum 2013 masih terdapat kekurangannya, akan tetapi dari aspek tanggung jawab kependidikan mereka selalu siap untuk melaksanakan pembelajaran berdasarkan tuntutan Kurikulum 2013.

\section{Pengetahuan Guru Tentang Kurikulum 2013}

Kaitannya dengan pengetahuan guru mata pelajaran Pendidikan Agama Islam dan Budi Pekerti tentang Kurikulum 2013 di SMP Negeri 6 Kota Makassar. Hasil temuan penelitian menunjukan bahwa guru Pendidikan Agama Islam dan Budi Pekerti belum sepenuhnya paham tentang Kurikulum 2013, akan tetapi substansi dasar Kurikulum 2013 dapat dimengerti oleh para guru. Bahkan, guru mempunyai motivasi intrinsik untuk mengetahui konsep dan aplikasi dalam menerapkan Kurikulum 2013. Kenyaataan ini dapat ditelaah dari beberapa pernyataan guru pendidikan Agama Islam sebagai berikut:

a. Sistim Kurikulum 2013 sebenarnya bagus karena kedudukan guru hanya menjadi fasilitator pembelajaran. Kalau masalah keingintahuan tentang Kurikulum 2013, sebagai guru bagaimanapun harus mengetahuinya dan untuk menunjang pengetahuan tersebut. Hal ini dilakukan dengan mencari tahu lewat internet. Akan tetapi, secara jujur pengetahuan tentang Kurikulum 2013 belum sepenuhnya dapat dipahami. Mungkin karena masih baru walaupun buku pedoman kurikulum sudah ada.

b. Kurikulum 2013 mengarah pada pembentukan karakter dan akhlak terpuji peserta didik. Akan tetapi, kami belum mengetahui sepenuhnya sehingga sebagai guru 
tentu mengharapkan bimbingan kaitannya dengan Kurikulum 2013 dan masih butuh pedoman lebih banyak dan lebih lengkap mengenai Kurikulum 2013.

c. Pengusaan secara idealnya tentang Kurikulum 2013 belum kerena kurikulum masih baru diterapkan, tetapi proses menuju kesempurnaan tetap ada. Bahkan, kami sebagai guru diwajibkan mengikuti pelatihan dan pastinya keberhasilan pelaksanaan kurikulum ini bergantung pada SDM guru dalam melaksanakan Kurikulum 2013.

Muatan pernyataan guru sebagaimana telah diungkapkan di atas, bila ditinjau dari aspek pengetahuan guru tentang Kurikulum 2013 secara menyeluruh dinilai masih kurang atau belum sepenuhnya dikuasai. Meskipun demikian, para guru mengerti kerangka dasar Kurikulum 2013 seperti orientasi kurikulum mengarah pada pembentukan karakter peserta didik maupun kedudukan guru hanya sebagai fasilitator pembelajaran. Selain itu, pernyataan guru yang masih mengharapkan bimbing-an dan membutuhkan pedoman Kurikulum 2013, menunjukan totalitas pengetahu-an guru masih berada pada kategori dramatik proses untuk menuju level pengetahuan yang memadai tentang Kurikulum 2013. Bahkan, ungkapan terkait keberhasilan pelaksanaan Kurikulum 2013 bergantung pada SDM guru, menegaskan bahwa adanya beban moril dari sisi keilmuan dan tentunya dapat memacu guru untuk menggali informasi sebanyak mungkin guna menunjang serta meningkatkan pengetahuan tentang Kurikulum 2013.

\section{Kesulitan Guru dalam Melaksanakan Proses Pembelajaran Pendidikan Agama Islam dan Budi Pekerti Berdasarkan Kurikulum 2013 di SMP Negeri 6 Kota Makassar}

Dampak dari perubahan kurikulum tampak pada reaksi psikis guru manakala dihadapkan kepada tugas profesional melaksanakan pembelajaran berdasarkan Kurikulum 2013. Kaitannya dengan kesulitan guru dalam melaksanakan proses pembelajaran Pendidikan Agama Islam dan budi pekerti berdasarkan Kurikulum 2013 di SMP Negeri 6 Kota Makassar, terdapat tiga aspek yang menjadi fokus pada bagian ini: (1) perencanaan pembelajaran Kurikulum 2013; (2) pelaksanaan pembelajaran Kurikulum 2013; dan (3) penilaian pembelajaran Kurikulum 2013.

\section{Perencanaan Pembelajaran Kurikulum 2013}

Hasil temuan penelitian menunjukan bahwa guru Pendidikan Agama Islam dan Budi Pekerti telah menyusun perencanaan pembelajaran dilakukan secara berkelompok melalui Musyawarah Guru Mata Pelajaran (MGMP). Melalui MGMP, diharapkan tersedia rancangan perencanaan pembelajaran terpadu pada kelompok guru mata pelajaran sehingga efektif digunakan di dalam pembelajaran.

Fakta penelitian menunjukkan, di dalam MGMP guru masih mengalami kesulitan dalam merancancang perencanaan pembelajaran ke dalam rancangan pelaksanaan pembelajaran (RPP). Keadaan tersebut dapat dianalisis dari pernyataan guru pendidikan Agama Islam dan Budi Pekerti sebagai berikut: 
a. Penyusunan perencanaan pembelajaran cukup susah terutama dalam memilih model pembelajaran yang sesuai karena harus dicocokkan dengan materi ajar dan media yang digunakan dalam belajar. Terkadang beberapa guru telah memilih metode pembelajaran yang dinilai sesuai, namun pada tahap implementasi tidak dapat digunakan secara efektif karena tidak sinkron dengan komponen lainnya. Dalam situasi itu, guru cenderung kembali ke metode ceramah mulai dari awal hingga akhir pembelajaran.

b. Guru kurang memahami model pembelajaran yang mesti digunakan dalam melaksanakan pembelajaran Kurikulum 2013 sehingga cenderung menggunakan cara-cara lama dalam melaksanakan pembelajaran.

c. Guru mengalami kesulitan dalam melakukan evaluasi pembelajaran karena objek penilaian yang kompleks meliputi penilaian pengetahuan, sikap dan keterampilan.

d. Kesulitan mengimplementasi evaluasi otentik disebabkan guru tidak terlatih menilai komponen penilaian yang berdiri sendiri dengan sistem predikat.

Berdasarkan keterangan dari sumber penelitian di atas, terdapat beberapa poin penting untuk menyimpulkan kesulitan guru mata pelajaran Pendidikan Agama Islam dan Budi Pekerti di SMP Negeri 6 Kota Makassar dalam menyusun perencanaan pembelajaran berdasarkan Kurikulum 2013. Pertama, ungkapan guru yang mengatakan pemilihan model pembelajaran yang tepat dalam proses pembelajaran dengan peserta didik termasuk aspek yang sukar dalam penyusunan perencanaan pembelajaran berdasarkan Kurikulum 2013 dapat dipahami karena sifatnya yang kontekstual dengan pendektan saintifik belum dipahami dengan baik oleh guru. Kedua, tingkat kesukaran penyusunan instrumen penilaian pembelajaran berdasarkan Kurikulum 2013 dikarenakan faktor terlalu banyaknya aspek-aspek penilaian yang berdiri sendiri dan konsekuensinya para guru dituntut untuk menyusun beragam rubrik beserta instrumen yang akan digunakan dalam proses penilaian peserta didik sangat kompleks.

Secara kritis, berdasarkan argumentasi di atas, dapat dikatakan bahwa guru sesungguhnya belum mampu merubah paradigmanya untuk menerima hal-hal baru yang lebih kompleks dan terstruktur dari pengalaman individual guru mengampuh pembelajaran dan melakukan penilaian.

\section{Pelaksanaan Pembelajaran Kurikulum 2013}

Hasil temuan penelitian menunjukan bahwa guru mata pelajaran Pendidikan Agama Islam dan Budi Pekerti dalam melaksanakan pembelajaran berdasarkan Kurikulum 2013, mengalami kesulitan dalam proses pembelajaran dengan pendekatan scientific. Dalam amatan peneliti, pendekatan ini telah dilakukan namun belum mengalir sebagaimana diharapkan. Hal ini terlihat dari ketidaktepatan guru mengnyinergikan dasar perencanaan dengan penggunaan media pembelajaran yang dapat menunjang pengetahuan peserta didik. Penegasan hasil pengamatan penulis tentang tata cara mengajar guru mata pelajaran Pendidikan Agama Islam dan Budi 
Pekerti, terungkap dari simpulan wawancara dengan beberapa peserta didik SMP Negeri 6 Kota Makassar berikut ini:

a. Guru mata pelajaran PAI dan Budi Pekerti dalam mengajar jarang menggunakan model belajar yang bervariasi.

b. Guru mata pelajaran PAI dan Budi Pekerti selama ini selalu ceramah saja dalam menjelaskan materi dan media belajar yang digunakan relatif tunggal.

c. Guru mata pelajaran PAI dan Budi Pekerti dalam pembelajaran monoton melakukan pembelajaran berkelompok, kecuali dalam kegiatan baca tulis Alquran dan umumnya siswa hanya diminta menyelesaikan soal-soal latihan atau menonton tayangan melalui LCD.

\section{Penilaian Pembelajaran Kurikulum 2013}

Hasil temuan penelitian menunjukan bahwa guru mata pelajaran Pendidikan Agama Islam dan Budi Pekerti dalam penilaian pembelajaran berdasarkan Kurikulum 2013, mengalami kesulitan pada proses penilaian terutama dalam mengevaluasi kompetensi sikap atau apeksi peserta didik. Hal tersebut terungkap dari pernyataan guru mata pelajaran Pendidikan Agama Islam dan Budi Pekerti SMP Negeri 6 Kota Makassar sebagai berikut:

a. Penilaian sikap secara umum sulit dilakukan karena objek perilaku peserta didik demikian kompleks baik secara individu anak maupun kelompok belajar.

b. Kebanyakan guru kurang memahami proses penilaian autentik pada Kurikulum 2013.

c. Secara umum guru kesulitan dalam memberi tindak lanjut hasil penilaian peserta didik.

d. Guru masih membutuhkan pelatihan dan penguatan penguasaan system evaluasi, baik secara klasikal melalui MGMP maupun individual melalui workshop atau semacamnya.

Berkaitan dengan uraian di atas, guru mata pelajaran Pendidikan Agama Islam dan Budi Pekerti di SMP Negeri 6 Kota Makassar, mengalami kesulitan dalam melakukan penilaian pembelajaran berdasarkan Kurikulum 2013, terutama penilaian kompetensi sikap peserta didik. Secara prinsipil tingkat kesulitan yang dialami guru disebabkan oleh beberapa hal. Pertama, penilaian sikap dinilai terlalu kompleks sehingga guru harus menyusun rubrik maupun instrumen penilaian yang akan digunakan untuk menilai peserta didik. Kedua, proses penilaian dilakukan pada saat kegiatan pembelajaran berlangsung yang cenderung memaksa guru harus mampu mengatur waktunya untuk menjalankan dua aktivitas sekaligus. Ketiga, mengutip argumen para pengawas yang menilai sebagian guru susah merubah paradigmanya terkait hal-hal yang terstruktur "guru tidak mau capek" seperti melakukan penilaian autentik berdasarkan Kurikulum 2013. 
Faktor Pendukung dan Penghambat Guru Mata Pelajaran Pendidikan Agama Islam dan Budi Pekerti serta Solusinya dalam Melaksanakan Kurikulum 2013 di SMP Negeri 6 Kota Makassar

Konstruksi peningkatan mutu pendidikan di sekolah sangat bergantung pada pengetahuan dan keterampilan guru dalam merumuskan program-program pembelajaran. Beberapa faktor yang dapat menunjang atau menghambat laju pengembangan pendidikan tersebut dapat diuraikan seperti berikut.

\section{Faktor Pendukung Guru}

Hasil temuan penilitian menunjukan bahwa faktor pendukung guru mata pelajaran Pendidikan Agama Islam dan Budi Pekerti dalam melaksanakan pembelajaran berdasarkan Kurikulum 2013 adalah: pertama, konten Kurikulum 2013 menekankan pembentukan karakter peserta didik cenderung memudahkan guru mata pelajaran PAI dan Budi Pekerti dalam merumuskan unit-unit kegiatan pembelajaran. Kedua, guru mata pelajaran PAI dan Budi Pekerti yang sudah mengikuti pelatihan kurikulum dan memiliki pemahaman tentang Kurikulum 2013 telah memiliki memahami pola pembelajaran Kurikulum 2013 sehingga relatif telah mampu mengimplementasi kurikulum itu secara operasional di dalam kelas. Ketiga, fasilitas sekolah telah cukup memadai dalam menunjang kebutuhan belajar peserta didik dengan Kurikulum 2013. Keempat, adanya upaya manajemen sekolah untuk mengefektifkan Musyawarah Guru Mata Pelajaran (MGMP) dan melakukan in house training untuk melatih para guru guna meningkatkan kompetensinya terkait Kurikulum 2013.

\section{Faktor Penghambat Guru}

Hasil temuan penelitian menunjukan bahwa faktor penghambat guru mata pelajaran Pendidikan Agama Islam dan Budi Pekerti dalam melaksanakan pembelajaran berdasarkan Kurikulum 2013 adalah: pertama, sosialisasi Kurikulum 2013 belum terlaksana dengan baik ke tingkat sekolah. Kedua, distribusi buku siswa dan buku guru belum terpenuhi secara optimal. Ketiga, guru belum sepenuhnya memahami prosedur authentic assesment pada Kurikulum 2013. Keempat, paradigma guru terhadap pembelajaran relative sulit berubah dan cenderung tetap dengan pembelajaran konvensional.

\section{SIMPULAN}

Pemahaman guru mata pelajaran Pendidikan Agama Islam dan Budi Pekerti tentang Kurikulum 2013 dapat ditinjau melalui dua aspek; sikap dan pengetahuan guru. Aspek sikap, guru secara umum setuju dengan pelaksanaan Kurikulum 2013 karena muatan kurikulum menekankan pembentukan sikap peserta didik dinilai sangat relevan dengan konsep pembelajaran Pendidikan Agama Islam dan Budi Pekerti. Dari sisi pengetahuan menunjukan bahwa guru belum optimal memahami substansi Kurikulum 2013. 
Kelemahan pengetahuan guru dalam berimplikasi pada lemahnya implementasi kurikulum ke dalam pembelajaran PAI dan Budi Pekerti yang dapat diklasifikasi ke dalam tiga aspek pembelajaran: perencanaan, pelaksanaan, dan penilaian pembelajaran.

Faktor pendukung guru untuk mengimplementasi Kurikulum 2013 adalah konten Kurikulum 2013 memudahkan guru merumuskan kegiatan pembelajaran, guru mata pelajaran PAI dan Budi Pekerti telah diikutkan dalam pelatihan Kurikulum 2013, dan adanya pelaksanaan in house training oleh pihak sekolah melalui MGMP.

Faktor penghambat guru secara prinsipil sosialisasi Kurikulum 2013 belum optimal serta instrument pendukungnya seperti buku pegangan siswa dan guru relatif lambat sehinggga mempengaruhi kinerja guru dalam melaksanakan pembelajaran berdasarkan Kurikulum 2013.

\section{CATATAN AKHIR}

1. Kunandar, Penilaian Autentik Penilaian Hasil Belajar Peserta Didik Berdasarkan Kurikulum 2013, Cet. I; Jakarta: PT Rajagrafindo Persada, 2013, h. 16.

2. Ibid., h. 17.

3. Forum Mangunwijaya VII, Menyambut Kurikulum 2013, Cet. I; PT Kompas Media Nusantara, 2013, h. 208-210.

4. Ramayulis, Profesi dan Etika Keguruan, Cet. II; Jakarta: Kalam Mulia, 2013, h. 1.

5. Departemen Pendidikan Nasional, Kamus Besar Bahasa Indonesia Edisi Keempat, Cet. I; Jakarta: Gramedia Pustaka Utama, 2008, h. 469.

6. Zakiah Daradjat, Ilmu Pendidikan Islam, Cet. VII; Jakarta: Bumi Aksara, 2008, h. 39.

7. Ahmad Tafsir, Ilmu Pendidikan dalam Perspektif Islam, Cet. IX; Bandung: PT Remaja Rosdakarya, 2010, h. 75.

8. Abd. Rahman Getteng, Menuju Guru Profesional dan Ber-Etika, Cet. VII; Yogyakarta: Graha Guru, 2012, h. 8.

9. Republik Indonesia, “Undang-Undang RI Nomor 20 Tahun 2003 tentang Sistem Pendidikan Nasional" , Cet. V; Jakarta: Sinar Grafika, 2013, h. 27.

10. Republik Indonesia, Undang-Undang RI Nomor 14 Tahun 2005 tentang Guru dan Dosen,". Cet. III; Yogyakarta: Pustaka Pelajar, 2012, “, h. 3.

11. Abd. Rahman Getteng, op. cit., h. 27.

12. M. Fadlillah, Implementasi Kurikulum 2013 dalam Pembelajaran SD/MI, SMP/MTS \& SMA/MA, Cet. I; Yogyakarta: Ar-Ruzz Media, 2014, h. 16.

13. E. Mulyasa, Pengembangan dan Implementasi Kurikulum 2013, Cet. III; Bandung; PT Remaja Rosdakarya, 2013, h. 68.

14. Yunus Abidin, Desain Sistem Pembelajaran dalam Konteks Kurikulum 2013, Cet. I; Bandung: PT Refika Aditama, 2013, h. 125.

15. Menteri Pendidikan dan Kebudayaan, Konsep Pendekatan Scientific Pendidikan Agama Islam dan Budi Pekerti, Badan Pengembangan Sumber Daya Manusia Pendidikan dan Kebudayaan Penjaminan Mutu Pendidikan: Slide PowerPoint PPT.2.1-1, 2014.

16. Yunus Abidin, op. cit., h. 79.

17. Lihat Menteri Pendidikan dan Kebudayaan RI, "Salinan Lampiran Peraturan Menteri Pendidikan dan Kebudayaan Nomor 66 Tahun 2013 tentang Standar Penilaian Pendidikan", Jakarta: Permendikbud, 2013, h. 3-4. 
18. Lihat Menteri Pendidikan dan Kebudayaan RI, "Salinan Lampiran Peraturan Menteri Pendidikan dan Kebudayaan Nomor 65 Tahun 2013 tentang Standar Proses Pendidikan Dasar dan Menengah", Jakarta: Permendikbud, 2013, h. 3.

19. Paulo Freire, Pendidikan Kaum Tertindas, Cet. VI; Jakarta: LP3ES, 2008, h. xxi.

20. Pius A. Partanto, Kamus Ilmiah Populer, Cet. I; Surabaya: Arkola, 2001, h. 175.

21. Emzir, Metodologi Penelitian Pendidikan: Kuantitatif dan Kualitatif. Cet. VI; Jakarta: Rajagrafindo Persada, 2012, h. 174.

\section{DAFTAR PUSTAKA}

Abidin, Yunus. Desain Sistem Pembelajaran dalam Konteks Kurikulum 2013. Cet. I; Bandung: PT Refika Aditama, 2013.

Daradjat, Zakiah. Ilmu Pendidikan Islam. Cet. VII; Jakarta: Bumi Aksara, 2008.

Departemen Pendidikan Nasional. Kamus Besar Bahasa Indonesia Edisi Keempat. Cet. I; Jakarta: Gramedia Pustaka Utama, 2008.

Emzir. Metodologi Penelitian Pendidikan: Kuantitatif dan Kualitatif. Cet. VI; Jakarta: Rajagrafindo Persada, 2012.

Fadlillah, M. Implementasi Kurikulum 2013 dalam Pembelajaran SD/MI, SMP/MTS E SMA/MA. Cet. I; Yogyakarta: Ar-Ruzz Media, 2014.

Forum Mangunwijaya VII. Menyambut Kurikulum 2013. Cet. I; PT Kompas Media Nusantara, 2013.

Freire, Paulo. Pendidikan Kaum Tertindas. Cet. VI; Jakarta: LP3ES, 2008.

Getteng, Abd. Rahman. Menuju Guru Profesional dan Ber-Etika. Cet. VII; Yogyakarta: Graha Guru, 2012. 